\title{
ATTITUDES OF THE STUDENTS AT THE NATIONAL SPORTS ACADEMY “VASSIL LEVSKI" TOWARDS WORK IN MULTICULTURAL ENVIRONMENT
}

\author{
Ina Georgieva Vladova
}

\begin{abstract}
Summary
Introduction: Racially, ethnically and religiously the World is diverse. This gives ground to acts of discrimination, social exclusion and inequality. Diversity implies an intercultural communication between the members of the different social groups and communities, that takes place in a multicultural environment. People of different ethnicity, religious background and mother tongue live in Bulgaria and the same diversity can be observed in the educational system on all levels. The most heterogeneous is the Roma minority. Methodology: The study of the opinions and the attitudes in respect of the work in multicultural environment (in the context of working with Roma students at school) has been realised by interviewing 185 students of the Teacher's Faculty of the National Sports Academy. For the achievement of the aim of the survey the methodology of collection of empirical information by pedagogical observation has been used - for preliminary formulation of the problem and by using a specially developed for the survey questionnaire. Results and Discussion: Most of the interviewed students state that they are tolerant of people of different ethnicity and religion $-57,8 \%$ of the respondents, while one fifth declared that they are not tolerant. Asked whether they would leave work if they have to work with Roma students the results of the variation analysis show that very few would be inclined do so $(M=1,64, \operatorname{Min}=1, \operatorname{Max}=5, S D=1,133)$. Conclusions: The results of the survey are important should some timely measures on university level be needed for the proper training of the future pedagogical experts.
\end{abstract}

Keywords: multicultural environment; intercultural communication; ethnic minorities

\section{Introduction}

There is a racial, ethnic and religious diversity all over the world. This is a premise for discrimination, social exclusion and inequality. The diversity, on the other hand, leads to intercultural communication among the members of different social groups in a multicultural environment. And each multicultural environment is characterised with its specifics depending on the groups which comprise it.

There are multicultural schools in the multicultural societies. Pupils of different ethnos, different religion and mother tongue can be gathered and can socialize within the same school and the same "classroom" ${ }^{1}$. In most cases, the teachers who work with these pupils do not belong to these minority groups. This trend is common for the schools in our country, too.

People of different ethnicity, religious background and mother tongue live in Bulgaria. This diversity is also observed in the education system on all levels:

- Orthodox Christians, Catholics, disciples of different Protestant churches, Muslims, Jews, etc.;

- Roma people (the most heterogeneous minority); Bulgarian Turks; Bulgarian Mohammedans; Jews; Armenians; Wallachians, etc.

This demographic picture calls for not allowing "the ${ }^{1}$ Classroom in a sense of pupils gathered in one class language of hatred" towards the different people, because the consequences according to Weis (1995) are alienation, marginalization, decreased opportunities, anxiety, oppression, exclusion. It is important that people should not be divided on the base of their ethnos, religion or mother tongue. Marginalization and social exclusion of groups from the Bulgarian population should not be tolerated.

On a macro level (the government of the country) there are a number of policies, laws and programs aimed at encouraging the equality and rights of the people from the different minority groups living on the territory of the country, as well as the struggle against discrimination. Policies for desegregation and inclusion of minority groups (mainly Roma community) in the education system and community life are present in the official government and non-government documents. However, despite these policies:

- Roma people are "at the bottom of the social-economical ladder", and they face discrimination and exclusion from different social spheres in the country which leaves them totally isolated and in risk of poverty;

- The religious minorities have religious freedom but nevertheless, there are cases of violence, threats, vandalism, hatred, tension rousing (United Nations, 2011). These registered trends are rather alarming. The Roma community itself is explicitly differentiated 
ethnically. The overcoming of this fact, as well as overcoming the problems connected with it, is a task of the whole community. To resolve these problems, we need to create a good intercultural communication and to join and integrate these people in the education system. It is important to point out that the Roma community in Bulgaria is not homogeneous, but heterogeneous (it consists of 4 main groups and a number of subgroups with various multicultural differences) (Tomova, 1998; United Nations, 2011).

The issue of intercultural communication and socializing in multicultural environment is discussed not only in summary standards and strategies from political point of view but also from business point of view. Due to globalization and the emergence of multinational companies and corporations' business is interested in these relations and interpersonal interactions (Lillis, Tian, 2010; Gut et al., 2017). Besides in business, this problem is very actual in psychological and pedagogical research and practice.

\section{Aim and Objectives of the study}

The aim of the research is to examine the attitudes of the students of the Teachers Faculty at NSA "Vassil Levski" toward working in a multicultural environment (in the context of the university and their work with Roma pupils). The attitudes explain the formation and development of one's Self as they constitute the relation between inner processes and social behavior (Erikson, 2013). Currently most of the problems in our education system are due to the negative social attitudes to the Roma community. For this reason, sometimes the integration of these children in school is problematic (but we do not exclude the negative attitudes of some of the Roma groups to education).
The examination of attitudes will help us, to a certain extent, to determine the level of tolerance among the future pedagogical experts to those who are "different" from them. The divergence is in the context of multicultural differences between learners and teachers. According to Michael P. Lillis and Robert Guang Tian cultural differences suppose divergent models of behavior, different living standards and way of life. Culture itself comprises attitudes, values, beliefs, opinions and behavior (Liillis, Tian, 2010). Tolerance, on the other hand, includes elements of rejecting and accepting: first, the unacceptable thing is noticed or rejected, and at a later moment it is accepted (Scanlon, 2003; Lundberg, 2017). The Living History Forum defines tolerance as: "an explicit stance to accept, respect or affirm individuals and groups based on skin colour, ethnicity, sexual orientation, beliefs, opinion, and several other categorizations" (Lundberg, 2017).

Due to the presence of multicultural environment in Bulgarian schools, the attitudes towards working with pupils from the minority groups should be considered because the presence of "pedagogical racism" is reported even worldwide (Lovern, 2012).

It is important that pedagogical specialists at schools, especially in the regions with mixed population, should increase their professional competences and quality of teaching under multicultural conditions. Thus, timely measures regarding their preparation could be taken.

\section{Methods}

The study of the opinions and the attitudes in respect of the work in multicultural environment (in the context of working with Roma students at school) was done among 185 full-time students of the Teacher's Faculty of the National Sports Academy at the beginning of 2016/2017 academic year (table 1). Table 1 Researched individuals

\begin{tabular}{llll}
\hline Variable & Sample (n) & Percentage (\%) & Percentage of all $^{*}$ \\
\hline Gender & 185 & & \\
Female & 68 & $36,2 \%$ & \\
Male & 118 & $63,8 \%$ & \\
Year & 185 & & \\
II & 93 & $50,3 \%$ & $57 \%$ \\
III & 54 & $29,2 \%$ & $26 \%$ \\
IV & 31 & $16,8 \%$ & \\
Master & 7 & $3,8 \%$ & \\
\hline
\end{tabular}

${ }^{*}$ percentage proportion from the total number of students in the respective academic year according to the Ministry of Education and Science

${ }_{* \star}^{*}$ the researched students study "Pedagogy of physical education" as their first and second major 
The average age of the researched individuals is $M=21.3$ years $(M i n=19, M a x=42, S D=2.22)$.

In order to fulfill the aim of the research a complex set of methods was applied to collect empirical information: pedagogical observation - for prior orientation and development of methods and instruments: an inquiry and a questionnaire specially designed for the research. The inquiry consists of questions regarding the students' gender; age; year of study; place of residence where the students finished high school; whether there were pupils of different ethnos, religion and mother tongue at their high school; whether they had any problems with such pupils. The questionnaire aims at surveying their attitudes to working with students of Roma origin (table 2).

Table 2 Instrument for measuring the students' attitudes to working with students of Roma origin

\begin{tabular}{lll}
\hline \multicolumn{1}{c}{ Instrument } & \multicolumn{1}{c}{ Scale description (Items) } & Rating \\
\hline $\begin{array}{l}\text { Students' attitudes to } \\
\text { working with Roma }\end{array}$ & Unidimensional scale measuring attitudes. The answers were given in \\
students & Cronbach's Alpha: $\alpha=0,71$ (n of Items=8). & 5-point Likert type scale: 1- \\
& The factor analysis outlines two factors with 4 items least true of me; 5 - most true \\
& each: attitudes to working with Roma students of me; 2, 3, and 4 are marginal. \\
& (Cronbach's Alpha: $\alpha=0,70)$ and attitudes to working \\
& with their parents, including their motivation for \\
& regular class attendance $(\alpha=0,743)$. \\
\hline
\end{tabular}

The methods used for quantitative assessment and analysis are: frequency, variation, comparative analyses (MannWhitney Test) and factor analysis. The results were statistically processed with "SPSS21 for Windows".

\section{Results and Discussion}

The results from the inquiry show that $73.5 \%$ of the researched individuals studied in multicultural environment (based on ethnos, religion and mother tongue) before enrolling at the NSA "Vassil Levski". It turns out that at school ${ }^{2}$, as well as outside its premises, most of the students did not have any problems with their peers of different ethnic group, (69\% on the school premises and $65 \%$ outside the school premises). They did not have any problems with pupils with different religion, either $(81,1 \%$ on the school premises and 73,5\% outside the school premises). As few as $2 \%$ of the students report they had frequent problems on the school premises. Only $7.6 \%$ of the students had problems with representatives of different ethnic group outside the school premises. Dimitrova-Denkova and Lefterov (2014) also discuss similar results from their research among students practicing combat martial arts: according to all researched individuals reli- gion is not a reason for conflicts and violence in the relations among athletes. As regards ethnic affiliation as a reason for conflicts, the researched sports students mark the answers "not really" and "sometimes". These results justify the conclusion that the students have intercultural experience because in their school years they had to socialize with representatives of other ethnic groups with different religion (at school and during their sports activities - in trainings and competitions). The results from the inquiry also confirm that $57.8 \%$ of them state firmly that they are tolerant to the "different" in the context of ethnos, race and religion against 20\% of them who do not share this opinion. The other $22.2 \%$ have not thought about this issue yet and do not have strong opinion on the subject.

The results from the test for evaluation of students' attitudes to working in multicultural environment are also hopeful. They are presented in Table 3.

Table 3 Students' opinion ${ }^{2}$

\begin{tabular}{llccc}
\hline Factor & \multicolumn{1}{c}{ Test } & n & M & SD \\
\hline I. & Students' attitudes to working with Roma students & 167 & 4,31 & 0,80 \\
II. & $\begin{array}{l}\text { Attitudes to indirect, additional work (incl. motivation, coordination with parents, } \\
\text { taking into consideration their holidays, skills improvement) }\end{array}$ & 182 & 3,72 & 0,96 \\
\hline
\end{tabular}

${ }^{2}$ Distribution of schools where the students studied on the base of their location: $20,7 \%$ are in Sofia; $31 \%$ in cities; $47,8 \%$ are in small towns, one school in Canada $(0,5 \%)$ 
In order to receive more details about the students' attitudes to working in multicultural environment we applied variation analysis (table 4). It must be noted that there is almost no difference in the mean values with both men and women. The results from the comparative analysis (Mann-Whitney Test) also show that along the factor gender there is no statistically significant difference.

The research of students' attitudes, which are in the base of the development of their professional philosophy and behavior, serves as a kind of attempt to predict their future working models. They currently believe that pupils are equal regardless their ethnos and religion and everybody should face the same requirements. They also think that in case there is lack of skills among some of the Roma pupils, they should do everything possible to improve this situation. Most of the researched students consider they are a factor for integrating Roma children in the education system and will work in this direction both with the pupils and with their parents.

The fact that there are low mean values as regards the holidays of different ethnic and religious communities is not alarming $(\mathrm{M}=2,87 ; \mathrm{SD}=1,52)$.

Table 4 Attitudes to working with Roma pupils

\begin{tabular}{|c|c|c|c|}
\hline Items & $\begin{array}{l}\text { Female } \\
\text { sample } \\
(\mathrm{n}=67)\end{array}$ & $\begin{array}{c}\text { Male } \\
\text { Sample } \\
(\mathbf{n}=118)\end{array}$ & $\begin{array}{l}\text { Total } \\
\text { Sample } \\
(\mathbf{n}=185)\end{array}$ \\
\hline & M SD & M SD & M SD \\
\hline $\begin{array}{l}\text { 1. When I become a PE teacher all students will be equal for me regardless their ethnos } \\
\text { and religion. }\end{array}$ & $4,480,83$ & $4,331,06$ & $4,391,00$ \\
\hline $\begin{array}{l}\text { 2. When I become a PE teacher my requirements to all pupils will be the same } \\
\text { regardless their ethnos and religion. }\end{array}$ & $4,600,76$ & $4,451,03$ & $4,500,94$ \\
\hline $\begin{array}{l}\text { 3. When I become a PE teacher, if I have to work with Roma pupils, I will treat them as } \\
\text { if they don't belong to this ethnic group. }\end{array}$ & $3,851,41$ & $3,741,33$ & $3,781,35$ \\
\hline $\begin{array}{l}\text { 4. When I become a PE teacher, if I have to work with Roma pupils who don't have } \\
\text { good skills and good motor abilities, I will try to improve them. }\end{array}$ & $4,271,10$ & $4,081,13$ & $4,151,12$ \\
\hline $\begin{array}{l}\text { 5. When I become a PE teacher, if I have to work with Roma pupils, I will try to } \\
\text { influence them and to motivate them to attend school classes regularly. }\end{array}$ & $4,271,10$ & $4,151,17$ & $4,201,14$ \\
\hline $\begin{array}{l}\text { 6. When I become a PE teacher, if I have to work with Roma pupils, I will try to } \\
\text { influence their parents' support as regard the regular attendance of their children in } \\
\text { PE classes and other school classes. }\end{array}$ & $3,931,18$ & $3,551,32$ & $3,681,28$ \\
\hline $\begin{array}{l}\text { 7. When I become a PE teacher, if I have to work with pupils of different ethnos and } \\
\text { religion, I will take their holidays into consideration. }\end{array}$ & $2,911,45$ & $2,851,56$ & $2,871,52$ \\
\hline 8. When I become a PE teacher, if I have to work with Roma pupils, I will quit my job. & $1,501,05$ & $1,731,17$ & $\mathbf{1 , 6 4 1 , 1 3}$ \\
\hline
\end{tabular}

In our country there is a centralized management of our school education system with unified government education standards, curriculum, as well as preliminarily set holiday dates and days-off.

Having in mind the size of the Roma population in our country, which is the biggest in $\mathrm{EU}$ as a proportion of the total number of the population (according to the unofficial data it is considerably more than the official statistics - approximately $10 \%$ ) (United Nations, 2011), as well as the students' personal observations, it turns out that they have formed a positive attitude to working with pupils from this group. When asked whether they would quit their job if they had to work with Roma pupils, few of them gave a positive answer $(M=1,64$, $\operatorname{Min}=1, \operatorname{Max}=5, \mathrm{SD}=1,133$ ).

\section{Conclusions}

The results from the research of the students' attitudes are hopeful because the problems with the Roma pupils are numerous. There should not be only administrative and legislative measures aimed at solving these problems. A lot of work should be done on a micro level and not in the form of a single act. This work is done mainly by pedagogical specialists - by teachers.

The results from the research are important. They enable universities to take timely measures as regards the preparation of the future pedagogical experts and the development of positive attitudes to working in multicultural environment (mostly with Roma pupils). 


\section{References}

Dimitrova-Denkova, A., Lefterov, E. (2014). The violence in the sports. In: 9th FIEP European congress, 7th International scientific congress "Sport, stress, adaptation”. Sofia, Bulgaria

Tomova, I. (1998). "Ethnic Dimensions of Poverty in Bulgaria," Report commissioned by the World Bank, p. 14, available at http://siteresources.worldbank.org/EXTGLDEVLEARN/Resources/IlonaTomova.pdf (5/05/2017)

United Nations (2011). General Assembly, Human Rights Council, Nineteenth session, Report of the independent expert on minority issues, available at: https://documents-dds-ny.un.org/doc/UNDOC/GEN/G12/100/19/ PDF/G1210019.pdf? OpenElement (5/05/2017)

Gut, A., M. Wilczewski and Gorbaniuk, O. (2017). Cultural Differences, Stereotypes and Communication Needs in Intercultural Communication in a Global Multicultural Environment. The Employees' Perspective. Journal of Intercultural Communication, ISSN14041634, issue 43, avaliable at: http://www.immi.se/intercultural/nr43/gorbaniuk.html (1/5/2017)

Eriksson, M. (2013). Attitude stability in a changing carnivore context: The foundations of attitudes towards the Swedish wolf policy. In: Linda Lundmark, Camilla Sand- ström (ed.), Natural resources and regional development theory (pp. 98-123). Umeå: Institutionen för geografi och ekonomisk historia, Umeå universitetGERUM Kulturgeografisk arbetsrapport

Scanlon, T. (2003). The Difficulty of Tolerance: Essays in Political Philosophy. Cambridge University Press.

Lillis, M. and R. Tian (2010). Cultural Issues in the Business World: An Anthropological Perspective. Journal of Social Sciences, 6 (1): 99-112; ISSN1549-3652

Lundberg, E. (2017). Mechanisms of tolerance: an anthology, The Living History Forum, Stockholm

Lovern, L. (2012). Trampling the sacred: multicultural education as pedagogical racism. International Journal of Qualitative Studies in Education, Vol. 25, Issue 7,867883

Weis, L. (1995). Identity formation and the processes of "othering": unraveling sexual threads. Educational Foundations, 9(1):17-33

Contact information: Vladova Ina, $\mathrm{PhD}$; National Sports Academy "Vassil Levski", Department "Psychology, Pedagogy and Sociology", Studentski grad, Sofia 1700, Bulgaria; Contacts: +35924014 (274); e-mail: vladova_ ina@abv.bg 